\title{
Use of biodiesel in Russian agricultural production
}

\author{
Kirill Zhichkin ${ }^{1}$, Vladimir Nosov ${ }^{2,3 *}$, Lyudmila Zhichkina ${ }^{1}$, Petr Burlankov ${ }^{2}$, Liliya \\ Ponomareva $^{2}$, and Evgeniy Ponomarev ${ }^{2}$ \\ ${ }^{1}$ Samara State Agrarian University, 2 Uchebnaja Street, Kinel, 446552, Russia \\ ${ }^{2}$ K.G. Razumovsky Moscow State University of technologies and management, 73 Zemlyanoy val, \\ Moscow, 109004, Russia \\ ${ }^{3}$ Academy of the Investigative Committee of the Russian Federation, 12 Vrubel Street, Moscow, \\ 125080, Russia
}

\begin{abstract}
The use of biodiesel in agricultural production is a prerequisite for reducing the cost price of manufactured goods. The purpose of the study is to identify how much equipment does the subject of the Russian Federation need for biodiesel production taking into consideration the structure of crop acreage, existing equipment, and available technologies. In the Samara region, a technology for production of biodiesel from vegetable oils was developed. Based on the needs in diesel fuel, a number of facilities needed for biodiesel production were determined. The amount of diesel fuel used for cultivation of the Samara region crop acreage was 77.1 thousand tons. To meet the needs of the region and reduce transportation costs, 5 biodiesel units should be located in every natural economic zone of the Samara region.
\end{abstract}

\section{Introduction}

By 2030 the world energy consumption is expected to increase by $53 \%$, and greenhouse gas emissions from fossil fuels - by $39 \%$ [1]. Currently, however, increasing attention is paid to the use of alternative fuels, due to the reduction in the worldwide supply of biogenic energy carriers, tightened exhaust emission standards, and limitation of carbon monoxide emission $[2,3,4,5]$. As an alternative fuel, biodiesel is one of the best options among other sources due to its environmental friendliness and functional properties similar to diesel fuel. For example, in the USA, in accordance with the adopted program, the share of renewable fuels has increased by $10 \%$ over the period from 2005 to 2017 [6]. In member states of the European Union, a Directive on the Promotion of the Use of biofuels was adopted, under which it is required to achieve at least $10 \%$ of biofuel in total fuel consumption by 2020 [7]. Biofuel production is also considered an important strategy to achieve the goals of the Paris Agreement [8].

Despite Russia being one of the largest oil exporters, many Russian scientific and manufacturing institutions have taken an active interest in production and consumption of

\footnotetext{
* Corresponding author: novla@list.ru
} 
environmentally friendly bioenergy carriers produced from renewable biological feedstock [9].

\section{Methods and materials}

In order to achieve the purpose of the study, we used statistical data provided by agricultural organizations of the Samara region, disaggregated by economic zones (Northern, Central and Southern) that differ in used technologies and varieties of crops. On 01/01/2020 1001 agricultural production units and organizations were registered. In the Samara region agricultural area accounts for 3799.8 thousand ha of agricultural lands, including 2871.2 thousand ha of arable lands (75.6\%), 95.1 thousand ha of fallow $(2.5 \%)$, 27.5 thousand ha of perennial planting $(0.7 \%), 50.7$ thousand ha of hayfields $(1.3 \%)$ and 755.3 thousand ha of pastures $(19.9 \%)$ [10].

Considering that the total area of arable lands in the Samara region is 2871.2 thousand ha and that annually agricultural productions consume $60 \mathrm{~kg}$ of diesel fuel per 1 ha of arable land, the average consumption of diesel fuel is 172.2 thousand tons per year.

The study used the monographic method, abstract-logical method, situational and system analysis, economic-statistical methods, and the method of expert evaluations.

\section{Results and discussion}

Fatty oils, less often - essential oils obtained from plants and algae are used as raw materials for biofuel production. Used cooking oil, animal fats and fish oil are also used in production $[11,12,13,14,15,16]$. Note that biofuel produced from specific oils has different properties $[17,18,19,20,21,22,23]$.

Table 1 shows crops cultivated in the Samara region that can be used in biofuel production.

Table 1. Production of oil from crops per ha.

\begin{tabular}{ccc}
\hline Crop & Kilograms of oil per ha & Litres of oil per ha \\
\hline Corn & 145 & 172 \\
Oat & 183 & 217 \\
Lupine & 195 & 232 \\
Soybean & 375 & 446 \\
Flax seeds & 402 & 478 \\
Pumpkin seeds & 449 & 534 \\
Mustard seeds & 481 & 572 \\
Milk-cap & 490 & 583 \\
Sunflower & 800 & 952 \\
Rapeseed & 1000 & 1190 \\
\hline
\end{tabular}

Rapeseed oil is oxidation-resistant and has an iodine number of less than 120, therefore, rapeseed oil is convenient to use in winter. Rapeseed gives good yields, that is why most areas are planted with this crop, which is later used for biofuel production.

Sunflower oil is also used for biofuel production. Currently, sunflower yields are lower than rapeseed yields, but it grows well in countries with a warm, dry climate. It has an iodine number of more than 120 (according to the European Standard EN 14214, it should not exceed 120), which is why it needs to be blended with other oils that contain less iodine. Potential possibilities of using other oil seeds as raw materials for biofuel production have not been fully explored yet.

For the production of biofuel with improved properties, the following crops can be used: 
crops with minimum concentrations of polyunsaturated fatty acids, such as linoleic acid $(18: 3)$;

crops with maximum concentrations of monounsaturated fatty acids, such as oleic acid $(18: 1)$, to ensure stability in combination with convenience of use in winter;

crops with minimum concentrations of saturated fatty acids (16:0) and stearic acid (18:0) for convenient usage in winter.

Several important properties of products of transesterification of the most common vegetable oils with methanol are presented in table 2.

Table 2. Properties of biofuel manufactured from different raw materials.

\begin{tabular}{ccc}
\hline Oil & $\mathrm{T}_{\text {пл }}{ }^{0} \mathrm{C}$ & Cetane number \\
\hline Rapeseed or soybean & -10 & $55-58$ \\
Sunflower & -12 & 52 \\
Corn & -10 & 53 \\
\hline
\end{tabular}

Currently, the most common biofuel is rapeseed methyl ester (RME), which is extensively used in Sweden, Germany, France and other countries. Up to $30 \%$ of it can be added to diesel fuel without additional engine modification. Western European countries have decided on mandatory addition of 5\% of RME to diesel fuel, though in some countries (Sweden, for example), RME is used as a substitute for diesel. Thus, we consider that the production volume of methylated vegetable oils will increase, agritechnologies will improve, which will result in the reduction of their cost prices to an acceptable level.

Many scientific research institution and universities, including the Samara State Agrarian University and Povolzskaya machinery testing station, conducted research on the use of RME biofuel, and developed utility flow schemes, fuel supply systems for tractors, adapted for the use of biofuel [24].

It was established that the reduction in engine power output of biofuel is insignificant, and fuel consumption increases by $5-8 \%$. Engine life does not change. Biofuel also has promising lubricating properties. Soot emissions decrease by $50 \%$, carbon dioxide - by $10-$ $12 \%$, sulfur - by $0.05 \%$ as compared with $0.2-0.5 \%$ for diesel fuel.

Technology for the conversion of vegetable oils to biofuel has developed considerably over the past years, especially in Tatarstan. The resulting products (diesel fuel, forage pulp and glycerin) are in demand, and their joint production makes the process cost-effective.

The simplicity of the technology and economic characteristics of the process make biofuel more appealing for agricultural producers, considering that diesel fuel is the main fuel in agriculture.

The first organization to produce biofuel in the Samara region was "Biosam" in Krasnoyarsk Krai.

On the basis of the laboratory of the Department of Tractors and Vehicles of the Samara State Agrarian University, the Biosam company tested biofuel samples produced by MIXER. The samples have demonstrated great antiwear and antiscuffing results [25].

Results of bench testing of engines running on alternative fuel conducted by Povolzskaya machinery testing station showed that:

engine power for blends of diesel and biofuel in different proportions is close enough to engine power for diesel fuel and is within tolerance limits, and differences are insignificant. A slight increase in engine power for $50 \%$ biofuel blend is due to high kinematic viscosity of blends, that allows reduction of leakage in plunger pairs;

fuel consumption rate for engines running on blend is higher than for diesel fuel due to the lower calorific value of biofuel.

We also calculated the comparative effectiveness of biofuel production. In accordance with this calculation, the cost price of 1 litre of own-produced biofuel is $30-50 \%$ lower than the wholesale price of diesel fuel. 
To determine the minimum number of biofuel production units, we should determine the amount of fuel consumed in the Samara region, which depends on cultivated crops and production technology.

Table 3 shows the structure of crop acreage by agricultural zones in percentage.

Table 3. Structure of crop acreage by agricultural zones of the Samara region (\%).

\begin{tabular}{cccccc}
\hline \multirow{2}{*}{ Area } & $\begin{array}{c}\text { Total crop } \\
\text { acreage }\end{array}$ & $\begin{array}{c}\text { Grain and } \\
\text { leguminou } \\
\text { s crops }\end{array}$ & $\begin{array}{c}\text { Industrial } \\
\text { crops }\end{array}$ & $\begin{array}{c}\text { Potato and } \\
\text { cucurbits }\end{array}$ & $\begin{array}{c}\text { Forage } \\
\text { crops }\end{array}$ \\
\hline Northern zone & 25 & 57.12 & 26.61 & 0.05 & 16.22 \\
Central zone & 32 & 53.95 & 28 & 0.58 & 17.47 \\
Southern zone & 43 & 56.4 & 34.13 & 0.64 & 8.83 \\
Region & 100 & 55.81 & 30.29 & 0.47 & 13.43 \\
\hline
\end{tabular}

Annual reports of organizations reflect crop acreage and material costs of petroleum products per crop. Thus, material costs of petroleum products per 1 ha can be calculated by dividing the material costs of petroleum products by crop acreage. Table 4 reports results for agricultural zones of the region.

Table 4. Material costs of petroleum products for cultivation of agricultural crops in zones.

\begin{tabular}{cccc}
\hline \multirow{2}{*}{ Crops } & \multicolumn{3}{c}{ Material costs of petroleum products per ha, thousand rubles } \\
\cline { 2 - 4 } & Northern zone & Central zone & Southern zone \\
\hline Grain and leguminous crops - & 1.49 & 1.19 & 1.79 \\
$\begin{array}{c}\text { total } \\
\text { Grain and leguminous crops }\end{array}$ & & & \\
(winter and spring) excluding & 1.66 & 1.19 & 1.71 \\
corn & & & \\
including: & 1.93 & 1.36 & 1.99 \\
winter grains & 1.34 & 1.18 & 1.34 \\
spring grains & 1.24 & - & 1.72 \\
Grain legumes & 1.30 & 1.03 & 2.20 \\
Grain corn & 1.84 & 3.58 & 1.89 \\
Industrial crops - total & 1.66 & - & - \\
Soybean & - & - & - \\
Milk-cap & - & - & 2.11 \\
Common flax (cultivation) & 2.02 & 3.58 & 1.34 \\
Grain sunflower & 1.30 & 1.76 & 0.66 \\
Potato and cucurbits - total & 0.83 & 0.76 & 0.34 \\
Forage crops - total & 1.06 & 0.30 & 0.69 \\
Perennial grass & 0.53 & 0.88 & 0.95 \\
Annual grass & 0.90 & 1.09 & \\
Silage corn and green corn & & & \\
\hline
\end{tabular}

Considering that 15 organizations have not planted any cropland with potato and cucurbits and that the share of this category in the structure of crop acreage does not exceed $0.5 \%$, we decided to apply the average value for all categories to this category.

To calculate material costs of petroleum products for every zone, we should multiply the coefficients for crops categories by crop acreage. 
Table 5. Material costs of petroleum products in cultivation of agricultural crops by areas of the Samara region in 2018.

\begin{tabular}{|c|c|c|c|c|c|}
\hline \multirow[b]{2}{*}{ Region } & \multirow{2}{*}{$\begin{array}{c}\text { Total material } \\
\text { costs of petroleum } \\
\text { products, } \\
\text { thousand rubles }\end{array}$} & \multicolumn{4}{|c|}{ including: } \\
\hline & & $\begin{array}{l}\text { Grain and } \\
\text { leguminous } \\
\text { crops }\end{array}$ & $\begin{array}{l}\text { Industrial } \\
\text { crops }\end{array}$ & $\begin{array}{l}\text { Potato and } \\
\text { cucurbits }\end{array}$ & $\begin{array}{l}\text { Forage } \\
\text { crops }\end{array}$ \\
\hline Samara & 2504543 & 1271943 & 1071010 & 11225.3 & $\begin{array}{c}150361 . \\
9\end{array}$ \\
\hline
\end{tabular}

Thus, 2504543.8 thousand rubles was spent for the cultivation of crops on the total area of 1488898.2 ha in the Samara region.

We analyzed trends in diesel retail prices using Yandex Quotation, and the results show that in 2018 the retail value of diesel fuel varied from 32.2957 to 33.6386 rubles per litre. However, considering the fact that agricultural units purchase large consignments of diesel fuel before field works, we can assume that the cost of diesel fuel is 32.5 rubles per 1 litre.

Therefore, we should divide material costs by cost of fuel purchase. Note that material costs of petroleum products relate to costs of diesel fuel, gasoline.

The structural analysis of petroleum products used over the past 3 years shows that diesel fuel accounts for $93 \%$, gasoline - for $7 \%$. Given the correction, we can determine the amount of petroleum products used to cultivate crops.

Table 6. Petroleum products used in cultivation of agricultural crops by areas of the Samara region in 2018.

\begin{tabular}{cccccc}
\hline \multirow{2}{*}{ Region } & $\begin{array}{c}\text { Petroleum } \\
\text { products, tons }\end{array}$ & $\begin{array}{c}\text { Grain and } \\
\text { leguminous } \\
\text { crops }\end{array}$ & $\begin{array}{c}\text { Industrial } \\
\text { crops }\end{array}$ & $\begin{array}{c}\text { Potato and } \\
\text { cucurbits }\end{array}$ & $\begin{array}{c}\text { Forage } \\
\text { crops }\end{array}$ \\
\hline Samara & 77062.9 & 39136.8 & 32954.2 & 345.4 & 4626.7 \\
\hline
\end{tabular}

\section{Conclusion}

The amount of diesel fuel used to cultivate the planted area of the Samara region is 77062.9 tons of diesel fuel. Based on described calculations of comparative effectiveness of biofuel production using MIXER-2 $11 \mathrm{AB}$ with a production capacity of 5000 tons per year, we were able to determine that 15 units will be enough to provide agricultural producers of the Samara region with biofuel.

For greater convenience, 5 units should be located in every agricultural zone of the Samara region.

\section{References}

1. M. Mofijur, H.H. Masjuki, M.A. Kalam, A.E. Atabani, M. Shahabuddin, S.M. Palash and M. Hazrat, Renew. Sust. Energ. Rev., 28, 441-55 (2013)

2. J. Goldemberg, S.T. Coelho, O. Lucon, Energy Policy, 32, 1141-6 (2004)

3. A. Demirbas, Energ. Convers. Manag. 50,14-34 (2009)

4. W. Thompson, J. Whistance, S. Meyer, Energy Policy, 39, 5509-18 (2011)

5. A. Poltarykhin, V. Nosov, L. Poletaeva, V. Avdotin, V. Grishin and M. Babakisiyev J. Environ. Manag. Tour., 10, 508-14 (2019)

6. S EPA 2005 Renewable Fuel Standard Program https://www.epa.gov/renewable-fuelstandard-program 
7. Renewable Energy Directive 2009 http://ec.eur-opa.eu/energy/en/topics/renewableenergy/biofuels

8. J. Goldemberg, Biofuels Bioprod. Bioref., 11, 237-8 (2017)

9. T.V. Yalyalieva, V.V. Nosov, T.S. Volkova, M.T. Tekueva, I.V. Pavlenko, Res. J. Pharm. Biol. Chem. Sci., 7, 1620-4 (2016)

10. K. Zhichkin, V. Nosov, L. Zhichkina, V. Zhenzebir and O. Sagina IOP Conf. Ser. Earth Environ. Sci., 421022066 (2020)

11. H. Fukuda, A. Kondo and H. Noda, J Biosci. Bioeng., 92, 405-16 (2001)

12. M. Canakci and H. Sanli, J Ind. Microbiol. Biot., 35, 431-41 (2008)

13. I.M. Atadashi, M.K. Aroua, A.R. Abdul Aziz and N.M.N. Sulaiman, Renew. Sust. Energ. Rev., 16, 3275-85 (2012)

14. I. Ambat, V. Srivastava and M. Sillanpää, Renew. Sust. Energ. Rev., 90, 356-69 (2018)

15. A. Karmakar, S. Karmakar and S. Mukherjee, Bioresour. Technol., 101, 7201-10 (2010)

16. G. Baskar and R. Aiswarya, Renew. Sust. Energ. Rev., 57, 496-504 (2016)

17. C-Y. Lin, H-A. Lin and L-B. Hung, Fuel, 85, 1743-9 (2006)

18. A. Abbaszaadeh, B. Ghobadian, M.R. Omidkhah and G. Najafi, Energ. Convers. Manag., 63, 138-48 (2012)

19. S.K. Hoekman, A. Broch, C. Robbins, E. Ceniceros and M. Natarajan, Renew. Sust. Energ. Rev., 16, 143-69 (2012)

20. E.F. Aransiola, T.V. Ojumu, O.O. Oyekola, T.F. Madzimbamuto and D.I.O. IkhuOmoregbe, Biomass Bioenergy, 61, 276-97 (2014)

21. T. Issariyakul and A.K. Dalai, Renew. Sust. Energ. Rev., 31, 446-71 (2014)

22. G. Knothe and L.F. Razon, Prog. Energ. Combust., 58, 36-59 (2017)

23. L.F. Chuah, J.J. Klemeš, S. Yusup, A. Bokhari and M.M. Akbar, J. Clean. Prod., 146, 181-93 (2017)

24. K. Zhichkin, V. Nosov and L. Zhichkina, IOP Conf. Ser. Earth Environ. Sci., 403, 012073 (2019)

25. K.A. Zhichkin, V.V. Nosov, V.I. Andreev, O.K. Kotar and L.N. Zhichkina, IOP Conf. Ser. Earth Environ. Sci., 341, 012005 (2019) 